веб-сайт. URL: https://www.culturology.academy/wp-content/uploads/KD5_ Shalinskyi.pdf

3. Лагода О. На «межі» дизайну: критеріальні оцінки і контури поняття «дизайн вражень» в контексті культури споживання. Науковий вісник НЛУ Украӥни: зб. наук.-техн. пращь. Львів: РВВ НЛТУ України, 2013. Вип. 23.18. С. 321-327.

4. Быстрова Т.Ю. Зачем дизайну культурология. Международный журнал исследований культуры. 4 (25). С. 5-15 : веб-сайт. URL : https://cyberleninka.ru/article/n/zachem-dizaynu-kulturologiya/viewer

5. Лагода О.М. Репрезентативні практики дизайну костюма в контексті еволюції художньо-проєктної культури : дис...док. мистецтвознавства: 17.00.07 - дизайн. Київ, КНУТД, 2020. 593 с.

DOI https://doi.org/10.30525/978-9934-26-004-9-110

\title{
NON-TRADITIONAL USE OF BOOK ILLUSTRATION IN MODERN UKRAINE
}

\author{
Oliinyk V. A. \\ Candidate of Study of Art \\ Senior Teacher at the Department of Arts \\ Kyiv University of Culture \\ Kyiv, Ukraine
}

It's no secret that the illustration in the book space, besides its direct purpose - to visualize the written content, has several secondary functions (presentation of an artist and publisher, popularization of a literary work, etc.).

In this case, it is logical and fair to further develop the multifunctionality of book illustrations, and, finally, the acquisition of a certain degree of autonomy by these pictures. We do not mean the complete autonomy of the latter, the distance from the literary plot. On the contrary, we note the exceptional affinity between the artistic and literary images, which was achieved by a talented illustrator, and thus this work received the right to become a business card of a literary work even beyond its borders.

In contrast to the Soviet era, when the tendency to use easel works as a book graphics, as well as the creation of artistic series based on literary subjects as separate artistic genre [3], now we can observe the applied usage of 
non-profit illustrative book pictures based on their acquisition of a certain «brand» over time.

Certainly, not all illustrative images in the books can claim for this level of recognition. The aforementioned naturalness of a combination of creative ideas of the writer and the artist, which can result in a qualitative reproduction of the desired image with the help of artistic tools, is not so often implemented. A lot of skillfully executed book illustrations remain only illustrations (although this is not an indicator of their inferiority). And only a few works, becoming especially popular among readers, visitors of art and book exhibitions, become truly recognizable, «folk», and sometimes even start their own style direction.

Such a tendency has successfully been succumbed by designers of various spheres of activity, adapting known book images for decorating their projects in order to evoke necessary associations of the consumer (customer). In particular, this phenomenon can be found among a variety of printing products (bookmarks, calendars, leaflets, etc.), as well as packaging and advertising products (posters, placards, etc.).

As an example, one should mention the works of the artists of the famous children's literature publishing house «A-BA-BA-GA-LA-MA-GA» Vladyslav Yerko (the posters of the New Year events for children are decorated with the image of the Snow Queen by this author) and Yevheniia Gapchynska, whose stylized characters (from books and not only) decorate various household items, packaging, souvenir and printed products. As an example, we can also mention a young illustrator Polina Doroshenko with her interesting images of Lesia Ukrainka's «Lisova Pisnia» (publishing house "Osnovy"), which were used for decorating a series of thematic leaflets, and other artists whose works are on a similar path.

The very idea of using well-known images to improve the effectiveness of advertising of certain goods is not new. Back in the early nineties of the last century, the tendency of reproduction of popular cartoon characters to illustrate the relevant books was observed in Ukraine in order to increase demand for them [3]. Now this advertising technique is widely represented by the design of packaging, mostly, aimed at children's audience.

It is obvious that such an impact on the consumer is positive and effective, as the products decorated with beloved images will automatically become more attractive. And examples of such secondary imitation are becoming more and more actualized, because in Ukraine, as a number of scholars note, the time has come for domination of visual culture $[1 ; 2]$.

It is likely that in this way the contemporary problem of coexistence in a single cultural space of paper and interactive books is being solved. Each of 
these two objects is gradually taking its niche: the traditional paper edition increasingly acquires the features of art-book, but the electronic one remains a purely informative bearer of knowledge.

At the same time, the book illustration, having received a new artistic reading, in another context partially loses its own original functions and is perceived as a decorative element, that is, it becomes an object of applied art.

It should also be noted that sometimes such «borrowing» occurs in an illegal way - without informing the artists themselves, who learn about such situations postfactum.

Famous Ukrainian illustrators Serhii Yakutovych, Kost Lavro, in their interviews, stressed the insecurity of the creative work of artists in front of the powerful mechanism of modern advertising, which has, above all, a commercial purpose. Today's technical progress makes it easy to use any image hosted on the Internet without reference to its author. In fact, the only factor that can hinder this unlawful process is human decency.

The main reason for this tendency is the change in the priorities in graphic arts and design that has been observed in Ukraine since the beginning of its independence in the context of general social and cultural restructuring and developed further on over the next two decades [3, p. 150]. This phenomenon meant the shifting of creative accents in visual arts, when the designer's idea gradually occupied the leading place, but not the artist's mastery. After all, application of computer design programs made it possible to imitate any handmade artistic technique without substantial time and physical expenses of a person.

Nowadays digital technologies allow to reproduce the whole spectrum of products of graphic design, including production of copies with variable information of each copy, protection of polygraphic products from forgery, provision of visual perfection of editions, influence the character of artistic design, change of its emotional-figurative structure, diversity of tactile and visual perception of the printed surface, provision of polygraph specimen with specific qualities [5]. Efficiency, a wide toolkit color palette, work with layers, textures, filters and effects, the ability to save and refine the image at different stages of visualization, to change the lighting, colorization, to abolish unsuccessful steps provide comfortable environment for creativity.

Gradually, among designers and representatives of the publishing teams in particular, there developed an attitude that the author's images are the material of common use, which can be bought (or got in some other way), and, if necessary, refined to fit their taste, to adapt to a particular project. And only during the last few years one can notice the slow increase of interest in «manual», exclusive work, the return of artistic value to a man-made image, 
which manifests itself in the desire of designers to combine the comfortable production capabilities of modern software tools with «artistic» and «handmade» features of the final graphic product.

Apparently, this phenomenon is difficult to definitely assess from the point of view of artistic value, since it possesses both positive and negative results, has progressive and «simplified» reasons. To a positive prospect, undoubtedly, we will ascribe the growth of popularity of such images, their actualization in everyday life, advertising of the artist-author. To the negative consequences we will include primitivization of the perception of illustrations by the viewer, involuntary change in the creative format and artistic content, and sometimes ignoring the author's concept of the illustrator or his copyright.

By the way, besides using the book illustrations themselves in advertising, modern researchers also notice the active introduction of well-known writers' images and even the titles of literary works [4] in this industry, which, under certain processing, are capable of becoming a bright advertising "chip".

As it can be seen, the potential of the book in modern society is increasing, automatically giving new opportunities to illustrative image. And whether this process will prove promising for the illustration itself - time will tell.

\section{References:}

1. Кюртен Й. Якісний дизайн і оздоблення - додаткові козирі книги в цифрову добу: Deutsche Welle. URL: http://dw.de/p/1AL1V (дата звернення: 17.03.2019)

2. Листвак Г.Б. Ілюстративний матеріал видання як додатковий засіб його промоції. Всеукраӥнська науково-практ. конферениія «Журналістика. Філологія. Медіаосвіта»: зб. наукових праць, 2-3 жовтня 2014 р., м. Полтава. С. 122-125.

3. Олійник В. Трансформації образної системи в дизайні української книги 1980-1990-х років: дис. ... канд. мистецтвозн-ва: 17.00.07. Київ, $2018.334 \mathrm{c}$.

4. Українська візуальна книга: видання і тенденції (назва з екрану) URL: $\quad$ http://bukvoid.com.ua/events/bookmarket/2017/12/13/083741.html (дата звернення: 25.02.2019)

5. Яремчук О. Художні засади синтезу проектних і виробничих процесів дизайну акциденції. Українська академія мистецтвв. Дослідницькі та науково-методичні прачі. №13. 2006. С. 237-246. 